\title{
Is Archean sulfur recycled in plume sources? New observations at Pitcairn
}

\author{
DR. JABRANE LABIDI ${ }^{1}$, JAMES DOTTIN III ${ }^{2}$, MATTHIEU \\ CLOG $^{3}$, CHRISTOPHE HEMOND ${ }^{4}$ AND PIERRE \\ CARTIGNY $^{5}$
}

${ }^{1}$ Institut de Physique du Globe de Paris

${ }^{2}$ University of Maryland

${ }^{3}$ SUERC

${ }^{4}$ CNRS UMR6538

${ }^{5}$ IPGP

Presenting Author: labidi@ipgp.fr

Volcanic rocks at the Pitcairn seamounts are erupted from a mantle plume that exhibits an extreme Enriched-Mantle-1 signature. The origin of this peculiar mantle endmember has remained contentious, and may involve marine sediments of various geologic ages, units from a lower continental crust, and/or metasomatized peridotites from a lithospheric mantle. Here, we report on the sulfur multi-isotopic signature $\left({ }^{32} \mathrm{~S},{ }^{33} \mathrm{~S}\right.$, ${ }^{34} \mathrm{~S},{ }^{36} \mathrm{~S}$ ) on 16 fresh submarine basaltic glasses from three Pitcairn seamounts. In addition to sulfur concentration and isotope ratios, we determined the concentrations of water, chlorine, copper, and all major elements. We also determined radiogenic isotope ratios of $\mathrm{Sr}, \mathrm{Nd}$, and $\mathrm{Pb}$ for the samples, and find signatures in full agreement with previous investigations of the EM-1 component at Pitcairn.

We find evidence for magmatic degassing of sulfur and water, for melts erupted $\sim 2,000$ meters below seawater level. For a series of basalts erupted on one seamount, with comparable major element signatures, the sulfur concentration appears correlated with eruption depth, and range between 1300 ppm S (collected $\sim 2,500$ meters below seawater) and $600 \mathrm{ppm} \mathrm{S}$ ( $\sim 2,000$ meters). Across this trend of sulfur loss, $\delta^{34} \mathrm{~S}$ values appear to decrease, consistent with equilibrium isotope fractionation at magmatic temperatures between dissolved sulfide and gaseous $\mathrm{SO}_{2}$.

Dissolved sulfides have homogenous $\Delta^{33} \mathrm{~S}$ and $\Delta^{36} \mathrm{~S}$ signatures, averaging at $+0.024 \pm 0.007 \%$ and $+0.02 \pm 0.07 \%$ vs. CDT, respectively (all $1 \mathrm{~s}$ ). The $\Delta^{33} \mathrm{~S}$ average is higher than MORB estimates by $\sim 0.020 \%$. Our new estimate appears is different from the previous investigation of the sulfur isotope composition of the Pitcairn mantle source using ion-probe techniques [1]. Our estimate nonetheless requires a substantial amount of surface-derived sulfur contributed to the Pitcairn source, which places constraints on the origin of EM-1 signature. We show that models involving metasomatized peridotites, lower crust, or Archean sediments, may be viable, but are restricted to narrow sets of circumstances. Instead, the contribution of Proterozoic marine sediments appear to be the most parsimonious explanation for EM-1 signature at Pitcairn.

[1] Delavault, et al,. (2016). Sulfur and lead isotopic evidence of relic Archean sediments in the Pitcairn mantle plume. Proceedings of the National Academy of Sciences, 113(46), 12952-12956. 